\title{
Preliminary report on Trichoptera from the headwaters of the Cuanavale, Cuito, Cuembo and Cuando Rivers in Angola
}

\author{
FERDINAND C. DE MOOR ${ }^{1,2,3,4,5^{*}} \&$ INA S. FERREIRA ${ }^{1,2,4,6}$ \\ ${ }^{1}$ Department of Freshwater Invertebrates, Makana Biodiversity Centre, Albany Museum, Grahamstown 6139, South Africa. \\ ${ }^{2}$ Department of Zoology and Entomology, Rhodes University, Grahamstown 6139, South Africa \\ ${ }^{3}$ South African Institute for Aquatic Biodiversity (SAIAB) Grahamstown 6139, South Africa \\ ${ }^{4}$ National Geographic Okavango Wilderness Project, Wild Bird Trust, 20 Loch Avenue, Parktown 2193 South Africa \\ 5 =f.demoor@ru.ac.za; ○ https://orcid.org/0000-0003-4624-7191

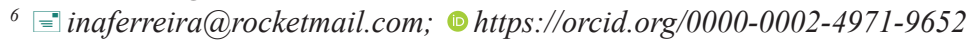 \\ "Corresponding author: "f.demoor@ru.ac.za
}

\begin{abstract}
Trichoptera larvae and adults were collected as part of an overall assessment of aquatic macroinvertebrate diversity in the major headwater tributaries of the Okavango and Zambezi River basins in Angola. This report documents one of the National-Geographic-funded, Okavango-Wilderness-Project expeditions undertaken between October and November 2016. A total of 21 sites on the Cuanavale, Cuito, Cuando, and Cuembo Rivers and some of their tributaries were sampled. Biotopes sampled in source lakes, headwater streams, pools, and large rivers included mostly sandy substrates, aquatic emergent and submerged vegetation, marginal vegetation and (rarely) bedrock, stones, or gravel. Light trap collecting was possible at only seven sites. With both adults and larvae collected, at least 55 species in seven families (Philopotamidae, Dipseudopsidae, Ecnomidae, Hydropsychidae, Hydroptilidae, Leptoceridae, and Sericostomatidae) were recorded. The Leptoceridae were the most abundant family, represented by ten genera and 22 species. There are a number of unnamed species which will be described in a separate paper.
\end{abstract}

Keywords: family, larvae, adults, faunistics, Okavango, Zambezi, river systems, Moxico

\section{Introduction}

When looking at a google earth map of Angola, the most striking observation is the amazing structure of river valleys in the highlands, feeding the Okavango Delta and other southern- and eastern-flowing water courses. The rivers in this southcentral region of Angola all flow through ancient Kalahari sands and the vegetation on the ridges is predominantly Miombo woodland with marginal shrub growth, comprising geoxylic suffrutex also described as "underground forest" by White (1979) and "geoxyles" by Simon \& Pennington (2012). The wide valleys between the ridges through which the rivers and headwater lakes extend, have extensive seasonally waterlogged grassland and sedge growth. In the high summer rainfall season, the waters of the lakes (which have been likened to dambos) and the rivers flowing out of them and through the Kalahari sand are very clear, fast-flowing, low in minerals and oligotrophic. The soils are poor in nutrients and not quite suitable for crop farming. The "ongote weed" (formed by the underground forest with its subterranean woody roots, trunks and branches with shrubby growths exposing only leaves, flowers and fruits growing above the ground) makes it very difficult to till the soil which is also nutrient-poor (Huntley 2017). The result of this is that these rivers, flowing through the Kalahari sands, supply high quality oligotrophic water to the Okavango River.

The Okavango Delta forms the largest freshwater wetland in southern Africa, and is one of Africa's biodiversity hotspots as well as the main source of surface water for over a million people. With funding and logistics support from National Geographic Society and the Wild Bird Trust, a multidisciplinary team of scientists and explorers have, since 2015, been surveying the rivers feeding this system in order to develop a sustainable conservation strategy for the Okavango Delta and its source rivers (NGOWP 2018). 


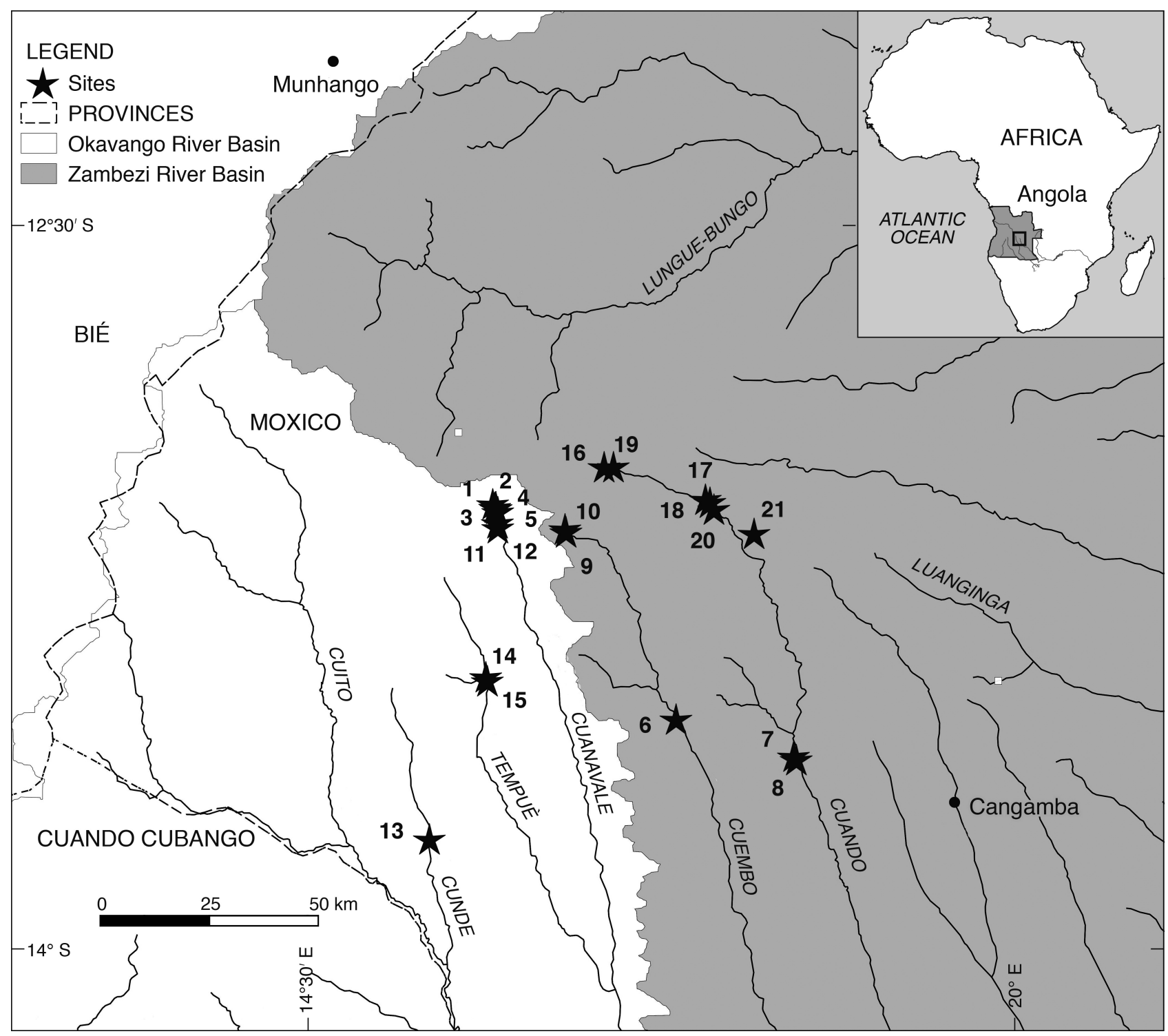

FIGURE 1. Location of sampling sites in the catchments of the Okavango and Zambezi Rivers in Angola where Trichoptera were collected, see Table 1 for details.

Research staff, from the Department of Freshwater Invertebrates at the Albany Museum, have been invited to participate in this Okavango Wilderness Project (OWP) and have taken part in three surveys to date. The rivers surveyed are in two major southern African catchments representing the Okavango and Zambezi River basins and include the following rivers and dates surveyed:

1. Cuanavale, Cuito, Cuembo and Cuando Rivers, 30 Oct-20 Nov 2016

2. Cubango River 4-16 May 2017

3. Lungue-Bungo River 13-29 April 2018

Only the first survey, conducted by the second author, is described in this article and, although all taxa of aquatic macroinvertebrates were collected, the focus of this article has been confined to the Trichoptera. 


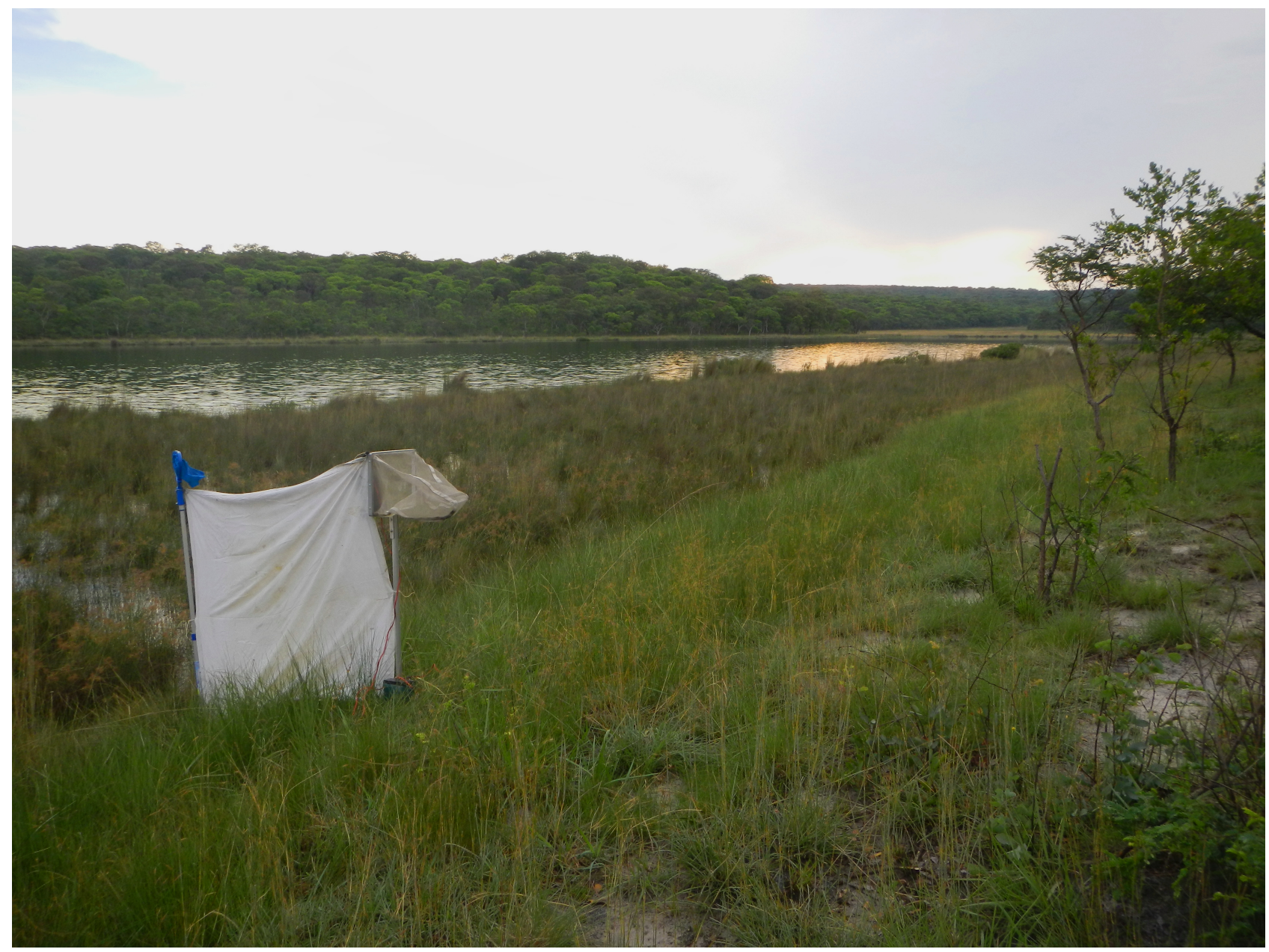

FIGURE 2. Cuembo River source lake (Salia Kembo) (Site 9). Note sheet light trap next to marshy vegetation.

\section{Material and Methods}

Aquatic macroinvertebrates from the waterbodies surveyed were collected with a long handled SASS net 300x300 mm with $1 \mathrm{~mm}$ mesh size (Dickens and Graham 2002) or a round frame hand net with $250 \mu \mathrm{m}$ mesh size. The nets were swept through marginal or submerged aquatic vegetation. In the case of harder substrates, such as sand, gravel, or stones and bedrock, the substrates were kicked vigorously, while holding the longhandled net downstream of the disturbed area, thus collecting invertebrates that were dislodged from the agitated substrate. Hand-picking of invertebrates off retrieved vegetation, woody snags, and stones was also undertaken. Light traps, comprising a 12-Volt superactinic light source were set over white trays filled with water and a few drops of detergent, and placed at sites close to waterbodies. Lights were also set on suspended white sheets next to the watercourse being sampled.

Twenty-one sites along the Cuanavale, Cuito, Cuembo, and Cuando Rivers were surveyed (Fig. 1). Waterbody types surveyed included source lakes, lake-outflow streams, river pools and runs, and waterbodies above and below waterfalls (Table 1, Figs. 2-7). At each of the sites surveyed, the waterbody was examined to identify specific aquatic biotopes (marginal or aquatic vegetation, sand, stones, gravel or bedrock, submerged woody substrata, and noted as either in or out of flowing water) which were then sampled. Wherever possible, sheet light traps were used to collect actively flying adult insects for approximately two hours after dusk (Fig. 2). Active collecting was not possible at two of the sites; therefore, pan light traps were set overnight at those sites. 


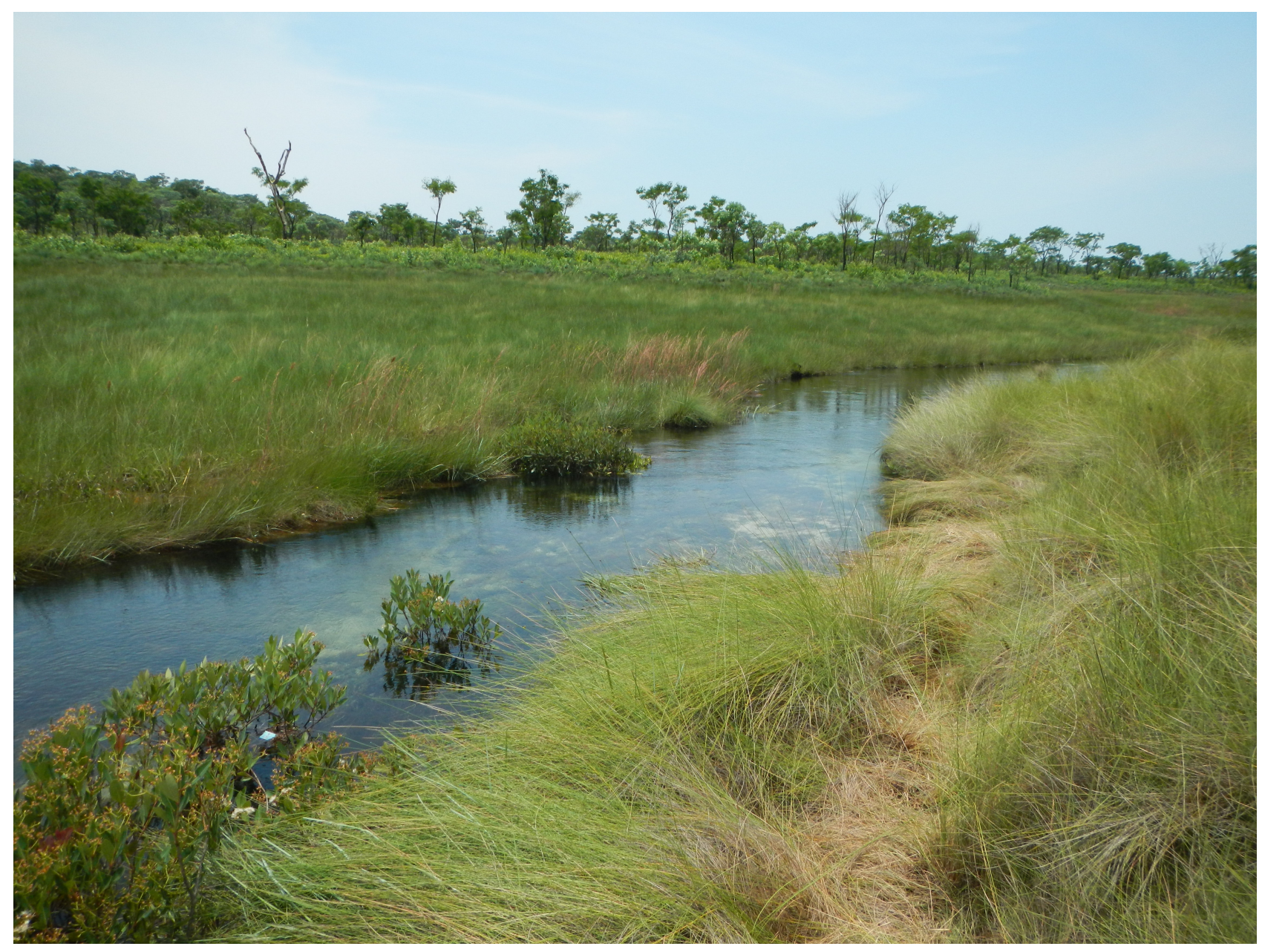

FIGURE 3. The Cuanavale River at the outflow of Cuanavale Source Lake (Site 4). Note grassland and woody herbaceous plants as marginal or in-stream vegetation and also the Miombo woodland and shrubby low growth on the hill slopes.

TABLE 1. Sites in the Okavango and Zambezi River Basins from which freshwater invertebrates were collected. (Latitude and Longitude in decimal degrees.)

\begin{tabular}{|c|c|c|c|c|}
\hline River System & Site \# & Locality & Latitude & Longitude \\
\hline \multirow{10}{*}{ 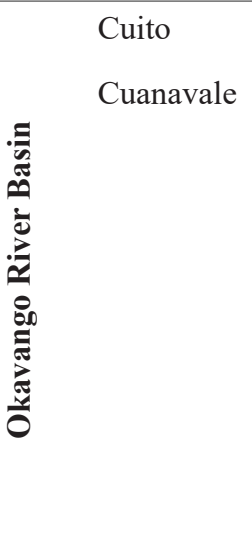 } & 13 & Cunde River: waterfall * & -13.773653 & 18.755386 \\
\hline & 1 & Cuanavale River: upstream of lake (closer to lake) & -13.088247 & 18.892975 \\
\hline & 2 & Cuanavale River: upstream of lake (further from lake) & -13.087015 & 18.892401 \\
\hline & 3 & Cuanavale source lake * & -13.089841 & 18.893946 \\
\hline & 4 & Cuanavale source lake: outflow of lake & -13.094569 & 18.896406 \\
\hline & 5 & Cuanavale source lake: Log-bridge downstream of outflow & -13.095038 & 18.896436 \\
\hline & 11 & Cuanavale River: at confluence with unknown tributary & -13.125504 & 18.899144 \\
\hline & 12 & Cuanavale River: unknown tributary at confluence * & -13.123346 & 18.898746 \\
\hline & 14 & Tempué River: at bridge & -13.442126 & 18.876675 \\
\hline & 15 & Tempué River: small unknown tributary & -13.442758 & 18.874902 \\
\hline
\end{tabular}


TABLE 1. (Continued)

\begin{tabular}{cllll}
\hline River System & Site \# & Locality & Latitude & Longitude \\
\hline \multirow{2}{*}{ Cuando } & 7 & Cuando River: unknown tributary & -13.602918 & 19.52924 \\
& 8 & CuandoRiver: campsite bridge * & -13.606964 & 19.532346 \\
& 16 & Cuando source lake: lake and outflow * & -13.003824 & 19.127249 \\
& 17 & Cuando River: motorbike bridge & -13.07274 & 19.341818 \\
& 18 & Cuando River: wetland in unknown tributary & -13.068417 & 19.343882 \\
& 19 & Cuando River: headwater site & -13.00428 & 19.146837 \\
& 20 & Cuando River: longbridge at village & -13.092266 & 19.359462 \\
& 21 & Cuando River: small unknown tributary (bridgeless crossing) & -13.142083 & 19.445024 \\
& 6 & Cuembo River: campsite bridge * & -13.526481 & 19.279708 \\
& 9 & Cuembo source lake (Salia Kembo) * & -13.136337 & 19.045293 \\
& 10 & Cuembo source lake (Salia Kembo): outflow stream & -13.144178 & 19.054132 \\
\hline
\end{tabular}

* Sites from which adult material was collected using light traps.

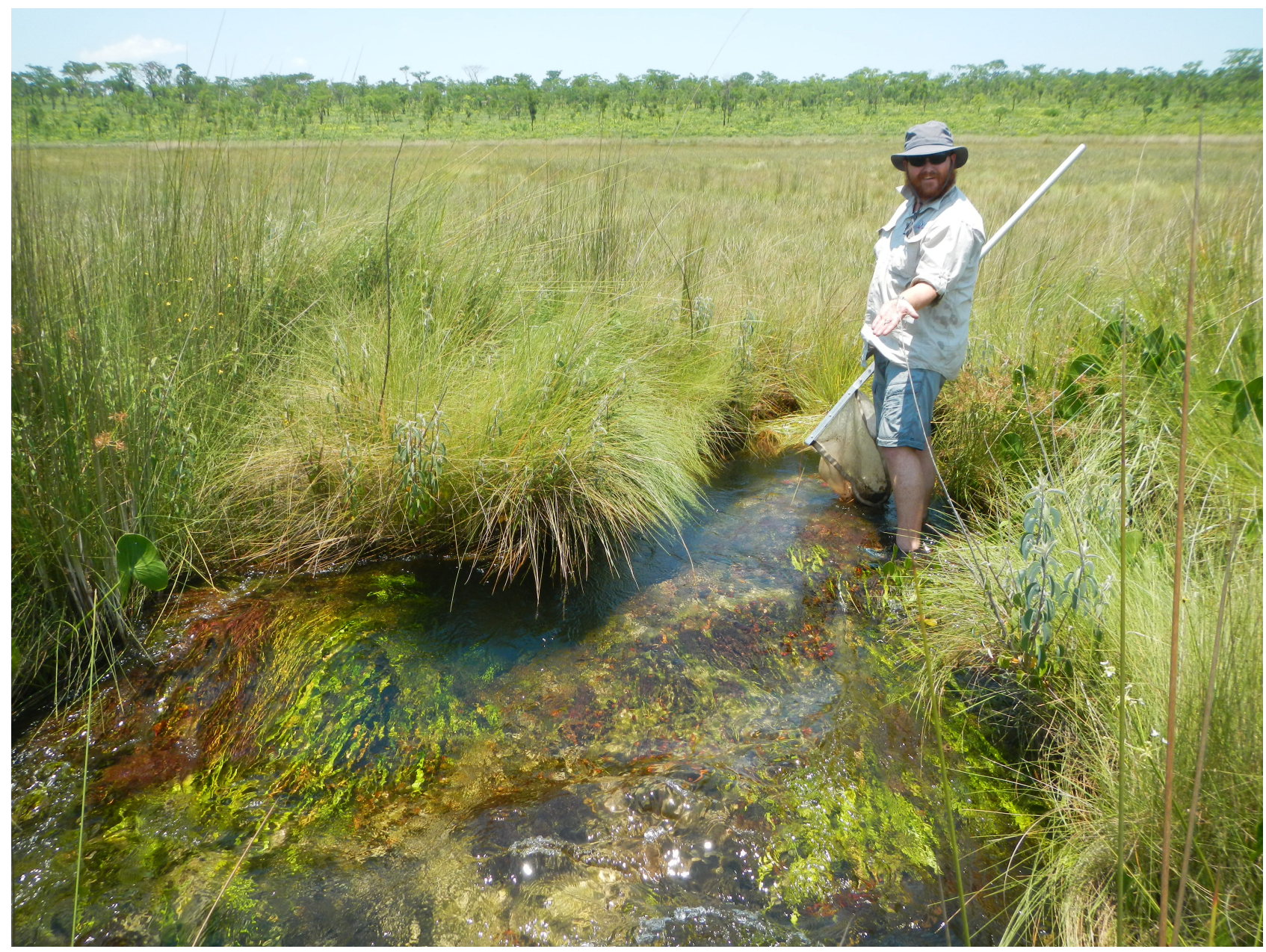

FIGURE 4. One of the pools on the Cuanavale River upstream of the source lake (Site 2). Note waterlogged grass, sedges, and submerged aquatic macrophytes on sandy substratum.

All collected material was preserved in $80 \%$ ethanol and assigned a catalogue sample number for each biotope at a site surveyed. The material of this survey was incorporated into the Albany Museum Central African Waters catalogue under entries CAW740 to CAW804. Each catalogue entry covers date, locality information, 
biotope sampled, and collector details. After sorting in the laboratory and identifying each taxon in a sample, specimens belonging to that taxon were designated with a unique alphabetic identifier linking it to the sample (e.g., CAW789R would be the first sample where Cheumatopsyche digitata was recorded). All Trichoptera were identified to generic and species levels where possible. All aquatic macroinvertebrates were collected for further study, but only Trichoptera are reported in this article.

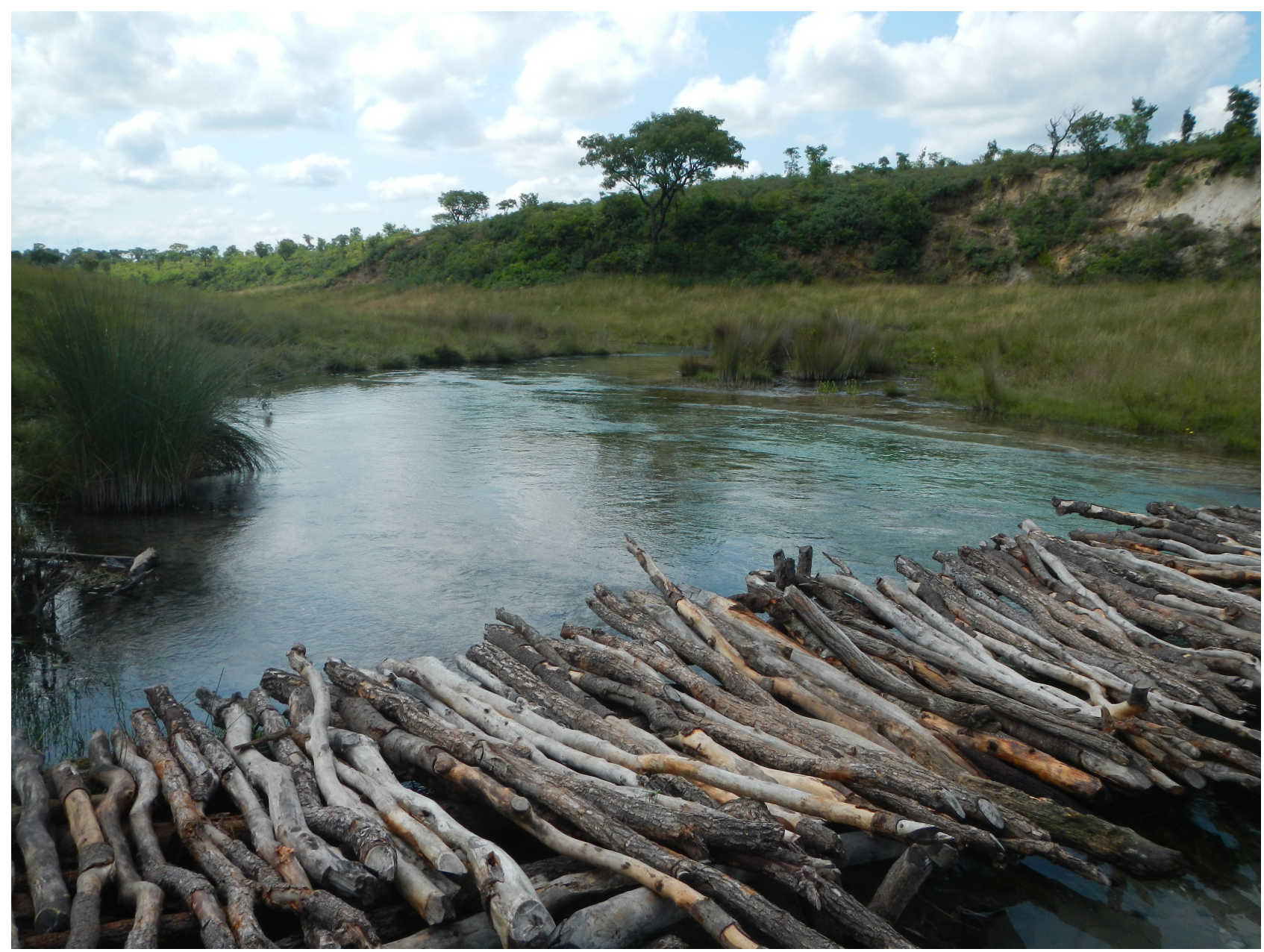

FIGURE 5. Cuando River. Longbridge near a village (Site 20). Note swift flowing clear water.

TABLE 2. Number of specimens of seven Trichoptera families (and percentage (\%) contribution in parentheses) collected from four major catchments in Okavango and Zambezi River Basins during October to November 2016.

\begin{tabular}{lcccc}
\hline \multirow{1}{*}{ Family } & \multicolumn{4}{c}{ River Catchment } \\
\cline { 2 - 5 } & Cuanavale & Cuito & Cuando & Cuembo \\
\hline Hydroptilidae & $24(7.2)$ & $7(8.9)$ & $32(15.0)$ & $263(33.5)$ \\
Philopotamidae & $47(14.0)$ & $12(15.2)$ & $7(3.3)$ & $44(5.6)$ \\
Dipseudopsidae & $0(0)$ & $0(0)$ & $1(0.5)$ & $0(0)$ \\
Ecnomidae & $13(3.9)$ & $8(10.1)$ & $37(17.4)$ & $139(17.7)$ \\
Hydropsychidae & $34(10.1)$ & $20(25.3)$ & $62(29.1)$ & $124(15.8)$ \\
Leptoceridae & $217(64.8)$ & $32(40.5)$ & $73(34.3)$ & $214(27.3)$ \\
Sericostomatidae & $0(0)$ & $0(0)$ & $1(0.5)$ & $0(0)$ \\
Total & $335(100)$ & $79(100)$ & $213(100)$ & $784(100)$ \\
\hline
\end{tabular}




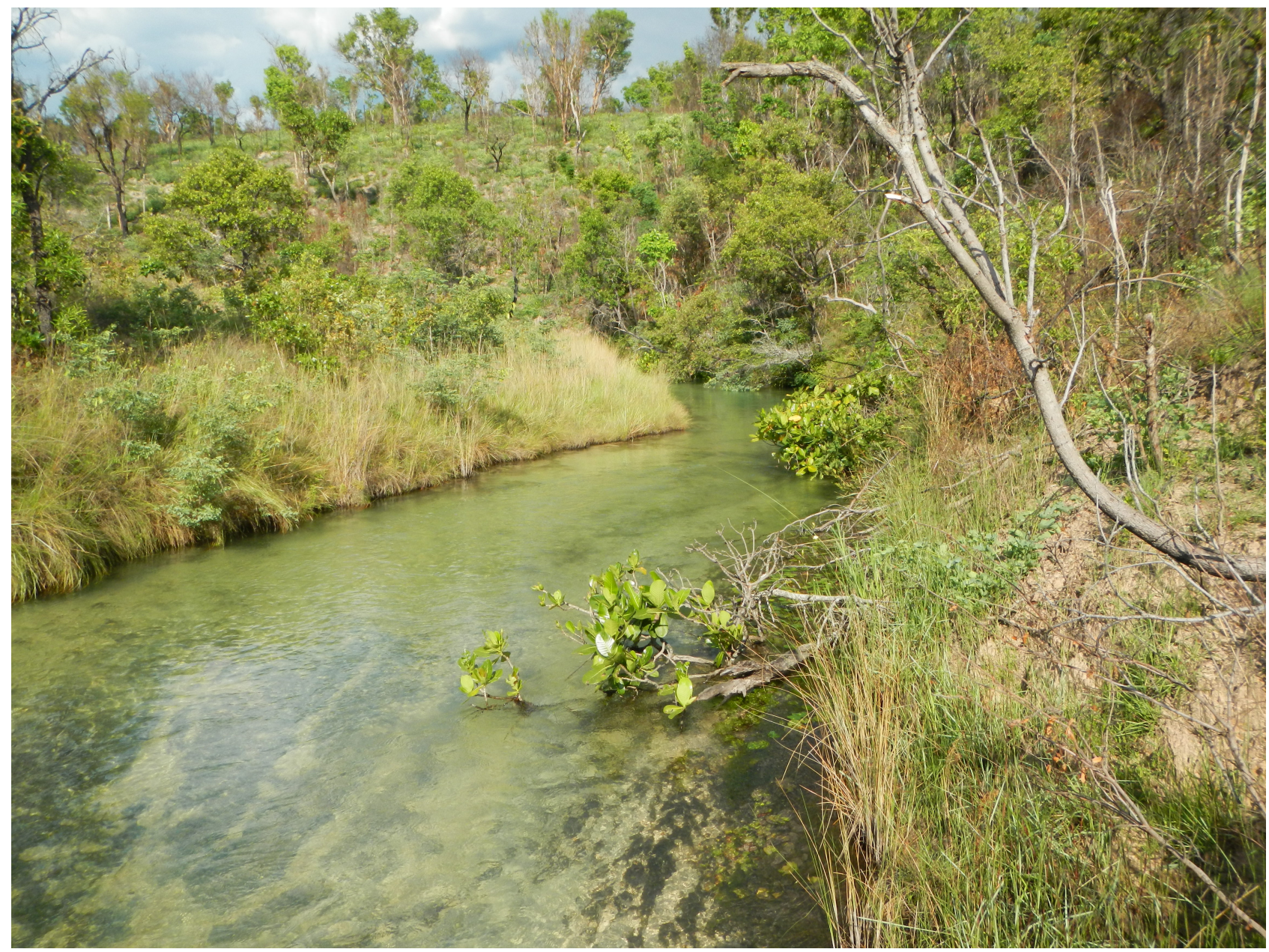

FIGURE 6. Cunde River, a tributary of the Cuito River, sampled upstream of a waterfall (Site 13).

\section{Results}

Seven families represented the Trichoptera fauna. The abundance of specimens in each family was recorded and evaluated for dominance from a combination of all the samples collected from each of the four surveyed rivers (Table 2). The individual taxa, identified and recorded as larvae or adults, are summarised and numbered (Table 3). Many species could not be identified because diagnostic details could not be discerned without proper genitalia preparations which were not carried out for this preliminary report. In such cases, specimens were given a temporary catalogue identifier number (e.g., "Cheumatopsyche sp. CAW757AU"). These identifiers are based on the catalogue number where the taxon in question was first identified.

\section{Discussion}

The rivers surveyed have not been previously studied and all material collected represents new information. In all four rivers surveyed, a numerical dominance of leptocerid caddisflies was observed, except Hydroptilidae were the dominant family along the Cuembo River (Table 2). Hydropsychidae were also well represented along all the rivers sampled. Although sampling effort was not the same for every site surveyed, the estimation of the relative abundance of specimens in each family can give an indication of the dominant caddisfly families in each river. The taxa identified thus far also reflect the greatest number of species in Leptoceridae with 22 species in ten genera, followed by Hydropsychidae with ten species in five genera, and Ecnomidae with eight species in one genus (two subgenera) (Table 3). Hydroptilidae are represented by ten species in 
seven genera. Altogether, 55 species of Trichoptera were recorded from the survey. However, there may be more taxa present because not all adult females could be identified to species and larvae may also represent species not collected as adults. The Museum do Dundo, Lunda Norte, Angola, was noted to have a collection of 67 species of Trichoptera of which 33 are described from Angola (Marlier 1965). There are records of three families - Polycentropodidae, Psychomyiidae, and Lepidostomatidae - not recorded in the 2016 survey. This recent survey records an additional family, Sericostomatidae (Table 3).

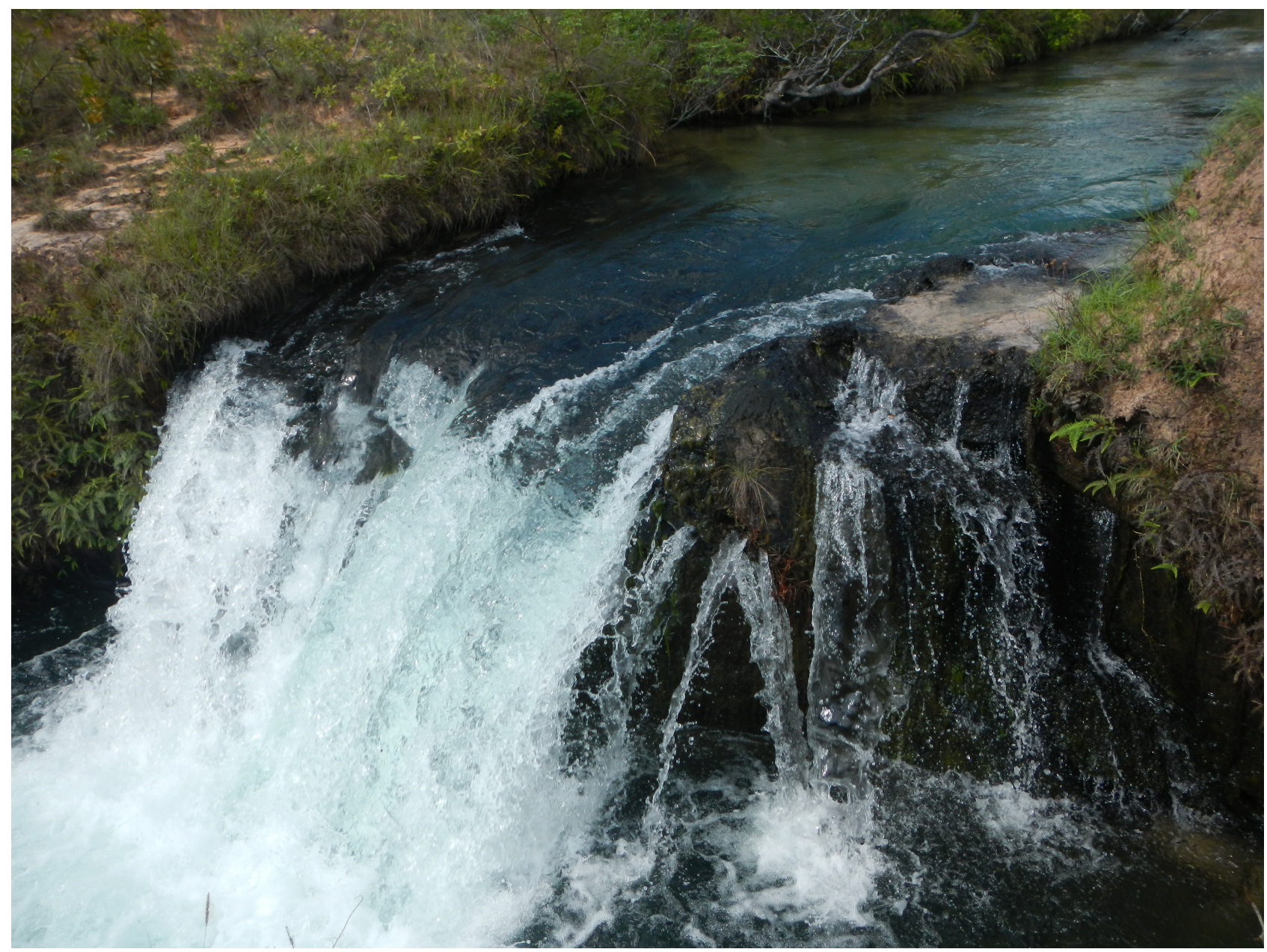

FIGURE 7. Waterfall on the Cunde River (Site 13). Note that only biotopes upstream and downstream of the waterfall were sampled.

Most of the source lakes and rivers sampled were on sandy beds with marginal grass and sedge vegetation, some partially submerged woody shrubs and short trees, as well as submerged aquatic macrophytes and filamentous green algae. The higher ridges rising above the grassland and sedge valleys are predominantly occupied by Miombo woodland with some elements of dry forest and shrubs comprising the terminal inflorescences of the underground forest.

The rivers studied in this survey are also remarkably fast-flowing during the rainy season and even small streams of less than a metre wide can be up to two metres deep. It is therefore not surprising that the dominant Trichoptera belong to the Leptoceridae and Hydroptilidae, comprising species that feed on, and make cases of vegetation. Because of the fast-flowing water, there are also filter feeders, as evidenced by the occurrence of Hydropsychidae, with Ecnomidae and Dipseudopsidae also recorded in reaches where sedimentation is evident.

We believe that analysis of the samples from the surveys conducted during 2017 and 2018 will reveal a more comprehensive picture of the diversity of Trichoptera in these seasonally waterlogged wetlands and will help to assess the role these caddisflies play in the functioning of the aquatic ecosystems. The Trichoptera will be further studied and new species will be described from the material collected in these surveys, the results of which will be published in future. 
TABLE 3. Preliminary list of Trichoptera species collected from four river catchments in the Okavango and Zambezi river basins during October to November 2016. Unique taxa are numbered and each is identified in quotation marks (“. ..") with an Albany Museum Central African Waters catalogue number (CAW740 to CAW804, corresponding with recorded date, locality information, biotope sampled, and collector details) and followed by a unique alphabetic identifier linking it to the sample.

\begin{tabular}{lccccc}
\hline \multirow{2}{*}{ Taxa } & \multicolumn{3}{c}{ River Catchment } \\
\cline { 3 - 5 } & & Cuanavale & Cuito & Cuando & Cuembo \\
\hline
\end{tabular}

\section{Hydroptilidae}

1. Orthotrichia "CAW 756F"

$\mathbf{X}$

2. Orthotrichia "CAW757F"

$\mathbf{X}$

Orthotrichia sp. larva

3. Tricholeiochiton sp. larva

4. Hydroptila sp. "CAW 764R"

5. Hydroptila sp. "CAW757AZ"

Hydroptila sp. larva

6. Tangatrichia "CAW 756T"

7. Oxyethira sp. larva

8. ?Stenoxyethira sp. CAW804AA

9. Hydroptilidae gen. sp. "CAW759D” larva

10. Hydroptilidae gen. sp. "CAW798J" pupa

\section{Philopotamidae}

1. Chimarra? divergens/elga/falcifera "CAW756D" $\quad \mathbf{X}$

2. Chimarra akana $\mathbf{X}$

3. Chimarra angolensis

Chimarra sp. "CAW764S” females

Chimarra sp."CAW744A" larva

Chimarra sp. "CAW758K" larva

Dipseudopsidae

1. Dipseudopsis ?sicumbana

\section{Ecnomidae}

1. Ecnomus ?aequatorialis/jacquemarti = ulmeri "CAW749E"

2. Ecnomus ?similans/dispar "CAW749S"

3. Ecnomus sp. "CAW 757AD"

4. Ecnomus sp. "CAW765P"

5. Ecnomus sp. "CAW796D”

6. Ecnomus sp. "CAW789P"

Ecnomus "CAW 756AB" female

Ecnomus sp. "CAW 757AC" female

Ecnomus sp. "CAW765B" female

Ecnomus sp. "CAW779F" female

X

$\begin{array}{ll}\mathbf{X} & \mathbf{X} \\ \mathbf{X}\end{array}$

$\mathbf{X}$

$\mathbf{X}$

$\mathbf{X}$

$\mathbf{X}$

$\mathbf{X}$

$\mathbf{X}$

$\mathbf{X}$

X

Ecnomus sp. "CAW759S” larva

Ecnomus sp. "CAW760D” larva

7. Ecnomus (Psychomyiellodes) sp. "CAW 757C"

8. Ecnomus(Psychomyiellodes)sp. "CAW796R"

Ecnomus(Psychomyiellodes)sp. CAW776F” larva

$\mathbf{X} \mathbf{X}$

$\mathbf{X}$

$\mathbf{X}$

$\mathbf{X}$

$\mathbf{X}$

$\mathbf{X}$

$\mathbf{X}$

$\mathbf{X}$

$\mathbf{X}$

$\mathbf{X}$

X $\quad$ X

$\mathbf{X}$

X $\quad \mathbf{X}$

...Continued on the next page 


\begin{tabular}{|c|c|c|c|c|}
\hline \multirow{2}{*}{ Taxa } & \multicolumn{4}{|c|}{ River Catchment } \\
\hline & Cuanavale & Cuito & Cuando & Cuembo \\
\hline \multicolumn{5}{|l|}{ Hydropsychidae } \\
\hline 1. Cheumatopsyche ?lestoni sp.gp "CAW 757AU" & $\mathbf{X}$ & $\mathbf{X}$ & & $\mathbf{X}$ \\
\hline 2. Cheumatopsyche ?dubitans sp. gp "CAW 757AV" & & & & $\mathbf{X}$ \\
\hline 3. Cheumatopsyche digitata "CAW789R" & & & $\mathbf{X}$ & \\
\hline 4. Cheumatopsyche brunnea "CAW796Q" & & & $\mathbf{X}$ & \\
\hline 5. Cheumatopsyche afra "CAW798T" larva & & & $\mathbf{X}$ & \\
\hline Cheumatopsyche sp. "CAW779U” female & & $\mathbf{X}$ & & \\
\hline Cheumatopsyche sp. "CAW757AT" female & & & & $\mathbf{X}$ \\
\hline Cheumatopsyche sp. "CAW763D” larva & $\mathbf{X}$ & $\mathbf{X}$ & $\mathbf{X}$ & $\mathbf{X}$ \\
\hline Cheumatopsyche sp. “CAW766B” larva & & & $\mathbf{X}$ & \\
\hline Cheumatopsyche sp "CAW776P" larva & & $\mathbf{X}$ & $\mathbf{X}$ & \\
\hline 6. Macrostemum capense & $\mathbf{X}$ & $\mathbf{X}$ & $\mathbf{X}$ & \\
\hline 7. Polymorphanisus elizabethae & & & $\mathbf{X}$ & \\
\hline 8. Aethaloptera dispar & & $\mathbf{X}$ & $\mathbf{X}$ & $\mathbf{X}$ \\
\hline 9. Aethaloptera maxima & $\mathbf{X}$ & & & \\
\hline 10. Leptonema? machadoi "CAW804AD” & $\mathbf{X}$ & & & \\
\hline Leptonema sp. "CAW 743K" Statzner \& Gibon 1984 sp. 2 larva & $\mathbf{X}$ & & $\mathbf{X}$ & $\mathbf{X}$ \\
\hline \multicolumn{5}{|l|}{ Leptoceridae } \\
\hline 1. Adicella sp. "CAW $756 \mathrm{~V}$ " female & $\mathbf{X}$ & & & \\
\hline 2. Athripsodes sp. nr bomana "CAW 757AM" & & & & $\mathbf{X}$ \\
\hline 3. Athripsodes sp. "CAW 804AI" & $\mathbf{X}$ & & & \\
\hline Athripsodes sp. "CAW 757AS" female & & & $\mathbf{X}$ & $\mathbf{X}$ \\
\hline Athripsodes sp. "CAW792P" larva & & & $\mathbf{X}$ & \\
\hline 4. Triaenodes ?aberrans "CAW 749D” & $\mathbf{X}$ & & $\mathbf{X}$ & \\
\hline 5. Triaenodes "CAW 757AI" & & & & $\mathbf{X}$ \\
\hline 6. Triaenodes sp. "CAW 804AH" & $\mathbf{X}$ & & & \\
\hline Triaenodes sp. “CAW773Q” larva & $\mathbf{X}$ & & $\mathbf{X}$ & $\mathbf{X}$ \\
\hline Triaenodes "CAW 756Y" female & $\mathbf{X}$ & & $\mathbf{X}$ & $\mathbf{X}$ \\
\hline 7. Ptochoecetis sp. "CAW 804AF" & $\mathbf{X}$ & & & \\
\hline Ptochoecetis sp. "CAW 749R" female & $\mathbf{X}$ & & & $\mathbf{X}$ \\
\hline 8. ?Ptochoecetis sp. “CAW 757AR" female & & & $\mathbf{X}$ & $\mathbf{X}$ \\
\hline 9. Oecetis sp. nr. machadoi “CAW 757AG" & & & & $\mathbf{X}$ \\
\hline 10. Oecetis aequatorialis "CAW 757AH" & $\mathbf{X}$ & & $\mathbf{X}$ & $\mathbf{X}$ \\
\hline 11. Oecetis sp. nr. akimi/carvalhoi "CAW 757AP" & & & & $\mathbf{X}$ \\
\hline 12. Oecetis ?luenae "CAW 804AN" & $\mathbf{X}$ & & & \\
\hline 13. Oecetis sp. nr. africana/seteni "CAW 804AM" female & $\mathbf{X}$ & & & \\
\hline Oecetis sp. "CAW 780T" larva & & $\mathbf{X}$ & $\mathbf{X}$ & \\
\hline Oecetis sp."CAW751Q" larva & $\mathbf{X}$ & & & $\mathbf{X}$ \\
\hline
\end{tabular}


TABLE 3. (Continued)

\begin{tabular}{|c|c|c|c|c|}
\hline \multirow{2}{*}{ Taxa } & \multicolumn{4}{|c|}{ River Catchment } \\
\hline & Cuanavale & Cuito & Cuando & Cuembo \\
\hline Oecetis sp."CAW759E" larva & $\mathbf{X}$ & & $\mathbf{X}$ & \\
\hline Oecetis sp."CAW795U” larva & & & $\mathbf{X}$ & \\
\hline Oecetis sp."CAW798AE" larva & & & $\mathbf{X}$ & \\
\hline 14. Oecetis sp."CAW800AC" larva & & & $\mathbf{X}$ & \\
\hline 15. Parasetodes ?nebulosus "CAW 749Q" & $\mathbf{X}$ & $\mathbf{X}$ & & $\mathbf{X}$ \\
\hline 16. Parasetodes sp. "CAW 757D" & & & $\mathbf{X}$ & $\mathbf{X}$ \\
\hline Parasetodes sp. "CAW797L" larva & $\mathbf{X}$ & $\mathbf{X}$ & $\mathbf{X}$ & $\mathbf{X}$ \\
\hline Parasetodes sp. "CAW797AG” larva & $\mathbf{X}$ & & $\mathbf{X}$ & \\
\hline 17. Ceraclea (Pseudoleptocerus)sp. "CAW 757 AK" & & $\mathbf{X}$ & & $\mathbf{X}$ \\
\hline 18. Ceraclea (Pseudoleptocerus)sp. "CAW 757 AL" & & & $\mathbf{X}$ & $\mathbf{X}$ \\
\hline 19. Leptocerina sp. nr. pediculata "CAW 757AN" & & $\mathbf{X}$ & $\mathbf{X}$ & $\mathbf{X}$ \\
\hline Leptocerina sp. "CAW 804AL" female & $\mathbf{X}$ & & & \\
\hline Leptocerina sp. "CAW 751L” larva & $\mathbf{X}$ & & $\mathbf{X}$ & \\
\hline 20. Setodes sp. aethiopica gp. "CAW 757 AF" & & & & $\mathbf{X}$ \\
\hline Setodes sp. "CAW759U” larva & $\mathbf{X}$ & $\mathbf{X}$ & & \\
\hline 21. Setodes sp. "CAW773U" larva & $\mathbf{X}$ & $\mathbf{X}$ & & \\
\hline 22. Leptocerus sp. nr. amphioxus "CAW 804AK" & $\mathbf{X}$ & & & \\
\hline Leptocerus sp. "CAW779Z" female & & $\mathbf{X}$ & & \\
\hline Leptocerus sp."CAW771Q" larva & $\mathbf{X}$ & $\mathbf{X}$ & & \\
\hline \multicolumn{5}{|l|}{ Sericostomatidae } \\
\hline 1. ?Aclosma sp. "CAW800M" pupa & & & $\mathbf{X}$ & \\
\hline
\end{tabular}

\section{Acknowledgements}

We acknowledge the help of a number of institutions and people that made funding available for research and travel assistance. They are: The National Research Foundation (NRF) incentive funding for rated researchers; the Directorate of Museums and Heritage, Eastern Cape, for supporting the research at the Albany Museum; and the National Geographic Okavango Wilderness Project, Wild Bird Trust, South Africa (NGOWP) for funding fieldwork, undertaking logistics for setting up camps, flying, feeding and driving researchers to collecting sites, and contributing to costs for sorting specimens; the Wild Bird Trust for administering the funds and coordinating the collecting trips; and the Halo Trust team for ensuring that we were in "landmine-cleared" areas when surveying. Rainer von Brandis, Chris Boyes, and Paul Skelton are also thanked for scientific and exploration leadership-; and Nonkazimulo Mdidimba and Zezethu Mnqeta for laboratory assistance in sorting samples. Sylvia de Moor is thanked for producing the map and two anonymous referees are thanked for reviewing the manuscript.

\section{References}

Dickens, C.W.S. \& Graham P.M. (2002) The South African scoring system (SASS) version 5 Rapid bioassesment method for rivers. African Journal of Aquatic Science, 27 (1), 1-10. 
https://doi.org/10.2989/16085914.2002.9626569

Huntley, B.J. (2017) Wildlife at War in Angola: The Rise and Fall of an African Eden. Protea Book House, Pretoria, 432 pp. ISBN: 978-1-4853-0611-5 (printed book). ISBN: 978-1-4853-0613-9 (ePub).

Marlier, G. (1965) Les Trichoptères du Musée de Dundo. Publicaçòes es Culturais da Companhia de Diamantes de Angola, Lisboa, 72, 13-80.

NGOWP (2018) National Geographic Okavango Wilderness Project (2017): Initial Findings from Exploration of the Upper Catchments of the Cuito, Cuanavale, and Cuando Rivers, May 2015 to December 2016, 368 pp.

Simon, M.F. \& Pennington, T. (2012) Evidence for adaptation to fire regimes in the tropical savanas of the Brazilian Cerrado. International Journal of Plant Sciences, 173, 711-723. https://doi.org/10.1086/665973

White, F. (1979) The Guineo-Congolian Region and its relationship to the other phytochoria. Bulletin Jardin Botanique National de Belgique, 49, 11-55.

https://doi.org/10.2307/3667815 